\title{
RISKS AND REMEDY IN ISLAMIC AND CONVENTIONAL LETTER OF CREDIT: JORDANIAN PRACTICES
}

\author{
Emad Mohammad Al-Amaren \\ Yarmouk University, Jordan \\ Email : amareenroma1993@gmail.com
}

\section{Che Thalbi Bt Md. Ismail}

University Utara Malaysia

Email : chet1048@uum.edu.my

\author{
Mohd Zakhiri bin Md. Nor \\ University Utara Malaysia \\ Email : zakhiri@uum.edu.my
}

Submitted: 10-05-2020 | Reviewed: 31-05-2020 | Published: 10-07-2020

\begin{abstract}
International trade and the movement of goods between parties living in different countries have spread in the last century and have become one of the fundamental features of the current trade. This proliferation of international contracts, of course, has its own problems. The problems of external Islamic or conventional letters of credit affect export, since letters of credit are considered a valuable tool used in financing foreign trade operations. Therefore, the problems faced by exporters in letter of credit reflect on and impact trade in general. Thus, the fewer the credit problems are, the more active foreign trade especially export will be. But if problems are relatively large, exports will contract. This study attempts to identify the problems of external and internal letters of credit facing the Jordanian traders and Jordanian Islamic and conventional banks, and to analyze them in an organized scientific manner, then proposing the appropriate recommendations to address these problems.
\end{abstract}

Keywords: Letter of Credit, Risks, Legal remedy, Islamic Bank, Conventional Bank, Jordan

\section{A. INTRODUCTION}

'The life blood of international commerce"(Alavi, 2017)is a statement which has been used by many scholars to describe the importance of the letter of credit. Letters of credit are among most popular trade finance instruments used in international trade. They look after the interests of both exporter and importer, so 
they are considered to be the most effective and safest approach to secure payment in international trade (Hao \& Xiao, 2013).

If Jordanian buyers choose to use letter of credit in international trade, they receive assurances that the value of the cargo will not be paid unless the seller shows evidence of discharging the obligations assigned to him under the contract of sale. On the other hand, sellers get their money after the presentation of compliance documents (Bouguerra and Bellaouar, 2015). However, there are many barriers that hinder the right implementation of letter of credit relating to economy. The reason behind this is due to the modernity of the letter of credit itself and the weakness of national and international laws to govern the subject of credit contracts, as the subject of the risks and legal remedy is a new method to create legal awareness in Jordan, and comprises many issues, such as letter of credit fraud.

In order to examine the risks faced Jordanian traders in letter of credits under the Jordanian system,this study is based on qualitative approach. It is so, to identify the problems of letter of credits from the point of view of Jordanian traders, and because of the lack of previous or direct studies in this field, interviews were conducted with Jordanian banks and Jordanian judges.

Since there is no specific requirement for the number of respondents in qualitative research,the respondents were selected in accordance to their position, experience in letter of credit and accessibility. Further, this study has followed the detailed analytical method of the international rules and norms related to documentary credits number 600 , in addition to the use of some books of jurisprudence in this regard, to find out the overall risks surrounding the process of letter of credit.

\section{B. LITERATURE REVIEW}

\section{B.1. JORDAN POSITION REGARDING EXPORT AND IMPORT}

Jordan is considered one of the developing countries that do its best to increase its exports and reduce the trade deficit to its lowest level(Bouguerra and Bellaouar, 2015). In order to highlight the risks that face the parties in letter of credit and to try finding appropriate solutions to facilitate trade processes, solving letter of credit problems leads to the flourishing of foreign trade, and as a result, export operations increase, and Jordan imports decrease, causing an increase in the trade balance deficit and thus the potential impact will be negative on Jordan national economy (Alawamleh, 2013).Chart 1 illustrates Jordanian exports and imports of goods during the period from 2011 to 2016 (Central Bank of JordanAnnual Report No. 53, 2016).

Charts 1 shows the decrease in Jordanian exports of goods during the period from 2011 to 2016 at a rate of $6.07 \%$, as well as showing the increase in Jordanian imports of goods during the period from 2011 to 2016 at a rate of $4.9 \%$, although, this increase has declined in the last two years. Charts 1 shows that Jordanian imports decreased about 2508.9 million Jordanian Dinar which accounts for $18.39 \%$ of the total imports.Astudy by Ahmad Thaher and Tawfiq Abdul - Jalil, which was entitled problems of export letters of credit from the point of view of Jordanian exporters, reached to this important result: The problems related to letter of credits contribute to the decline of import and export(Thaher \& Abdul Jalil, 2006)since letter of 
credits are considered a valuable tool used in financing foreign trade operation. The importance of documentary credit appears in two sides: First: It provides confidence to the parties of the international sales contract. The second is related to the problem of excessive costs of goods and shipping, and this undoubtedly overburden the buyer (the importer) financially and may threaten him with bankruptcy(Ramadan, 2007).

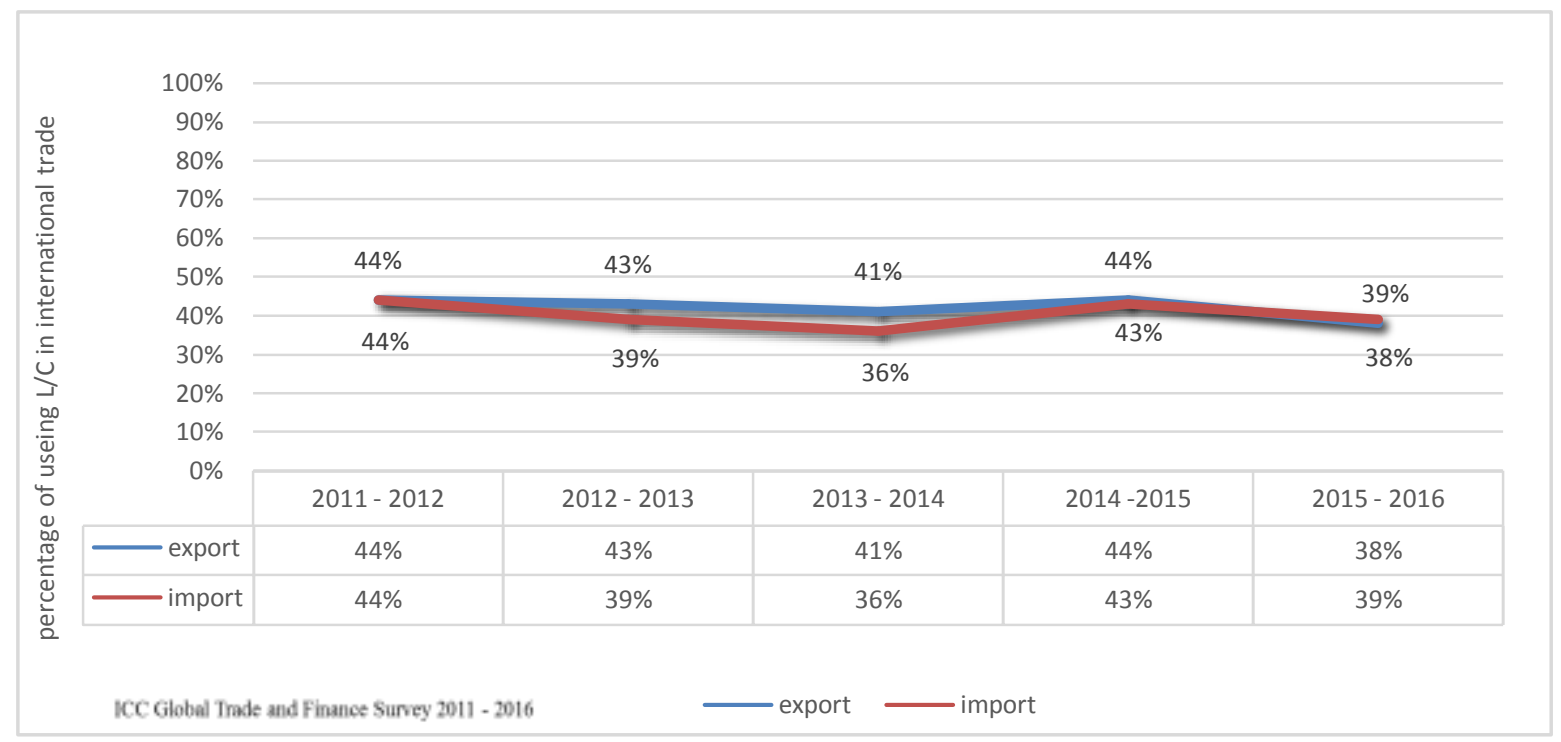

Chart 1. Application of Letter of Credit

Recently, open account is used more frequently in international trade than letter of credit which was the primary source of funding in the last decade, as the situation has currently shifted to the use of open account(Al-Amaren \& Ismail \&Nor, 2020). The obvious reason behind this huge decline of letter of credit usage is due to the enormous risks that surround letter of credit. This makes buyersor even sellers think one thousand times before choosing this contract to complete their business.

\section{B.2. TYPE OF RISK IN JORDAN PRACTICE}

Letters of credits are still playing a leading role in international commerce (Alrabei, 2017). They are considered one of the international contracts which are defined in general as a promise to which the law attaches a legal duty and also provides a remedy for breach of that duty ( $\mathrm{Al}$ Amaren and Rachma Indriyani, 2019; Al Amaren, 2018).

Although letter of credit may achieve this guarantee and may grant security to all parties involved, this banking contract may involve some risks during its implementation(Hao \& Xiao, 2013)either for Jordanian buyers (applicants) or Jordanian sellers (beneficiaries) or Jordanian banks (issuing or conforming). Because letter of credit is subjected to international rules and provisions, and because of the lack of legislative texts in Jordan(Alawamleh, 2013) as well as the lack of sources and legal documents, researches, and because 
Jordanian courts decisions were absent in addressing risks during its implementations (Metchnikoff, 1956), many risks has appear in this field:

\section{Risks Related to Cargo}

Dishonest sellers may take advantage of distance to ship goods of inferior quality and less quantity. Therefore, the letter of credit risk for the buyer is that he may expedite the amount of the credit to the bank so that the latter will pay it to the beneficiary if the documents provided by the beneficiary match the required documents (Obeidat \& Al-Khashraom, 2009). Since letter of credit deals with documents that indicate goods, not the goods themselves, Jordanian buyer may face the problem of reciving goods which are not identical to the underlaying contract. The reasion behind that is due to the fact that letter of credit contract deals with documents, not goods, in addition to that the bank's job is to examine the documents and not the goods.

\section{Fraud Risk}

Fraud in general means uncertainty(Zhang, 2012).While, fraud in letter of credit represents unlawful action committed either by seller or buyer, to obtain financial benefit by taking advantage from the loophole in letter of credit mechanism, thereby resulting in economic loss to either applicant or beneficiary (Han \& Nelen \& Joo, 2015).

Although, the bank's commitment to pay to the seller is linked with thepresentation of the required documents, the issuing or conforming bank has the right to withhold beneficiary from drawing the money which represents the value of the goods when there has been fraud committed by the beneficiary(Meral, 2012). Fraud is one of the important risks that banks and buyers face in letter of credit transactions, it is described as 'a cancer in international trade'(Monteiro, 2007), for that, banks can reject payment if they have unmistakable evidence of fraud.

On the first hand, autonomy principlein letter of credit facilitatesinternational trade processby depending on the compliance of the required documents presented to the confirming or issuing bank to honor the credit. On the other hand, autonomy principle or independence principle can increase the possibility of fraud by giving dishonest seller the chance to present non-genuine documents which are in compliance with the terms and condition of the credit, but not in a compliance with the terms and condition of the underlying contract of sales (Hamad, 2016). In most common letters of credit fraud cases, buyers and banks are the victims (Hamad, 2016)(Al-Amaren \& Ismail \&Nor, 2019).

Fraud committed by the beneficiary is the most dangerous and widespread fraud worldwide, result in overwhelming effects on the applicant (Rosmawani \& Mahdzan, 2014). However, the development of new fraud forms has resulted in a growing number of legal cases in which sellers can be fraud victim also(Hamad, 2016)what follows are some fraud scenarios in letter of credit transaction.

(1) Letter of credit working system can be a good motivation to afraudulent beneficiary to defraud the applicant by presenting a compliance documentsto the bank, but these documents are not in a compliance with the terms and condition of the underlying contract of sales(Hamad, 2016). Sometimes, 
the seller ships goods of less quantity or low quality, while sometimes ships garbage, filling the containers with useless things. After that, thefraudulent beneficiary obtains payment from the issuing or conforming bank and disappears before the cargo reaches the port of destination(Shohana, 2008). Other techniques for defrauding the applicant have been explained in the UNCTAD 2003 Report.

(2) In letter of credit, the beneficiary has to submit the required documents (normally, these documents are bill of lading, certificate of origin, the commercial invoice, and the insurance policy) to the issuing bank or to the confirming, negotiating, or advising bank (Shohana, 2008). In the same time, the beneficiary has to send the required documents to the applicant in order to advise him regarding name of ship and time of arrival to the port of destination (Hamad, 2016). Fraudulent applicant can forge the original documents received from the beneficiary, present them to the carrier upon the arrival of the ship at the port of destination and get the delivery order of releasing the cargo, leaving the bank with the obligation to pay the beneficiary the value of the goods (Shohana, 2008).

Interestingly,UCP 600 has taken an absolute silent position about the risk of fraud, leaving it open to national legal systems(Hamad, 2017).

The ICC practice is considered unsuccessful because there are many countries like Jordan which completely depend on the UCP to a level that makes these rolls as enforcement law, and to make the situation worse, many countries like Jordan did not regulate letter of credit and they depend $100 \%$ on the UCP rules which are already not complete, and that leads to a huge vacuum on the legal text governing the letter of credit in Jordan.

\section{Risk of Issuing Bank's Negligence}

This risk might happen if the issuing bank depends only on the documents checking mechanism of the confirming and negotiating banks. This practice could lead to send problematic documents to the applicant. As a result, the applicant can face the risk of not receiving the release order from the carrier because of presenting problematic documents(Hamad, 2017). This practice could lead to a devastating effectif the bank has already honored the presentation, because if the bank already pays, there is almost no possibility to restitute the money from the beneficiary.In addition, the buyer cannot obtain the release order from the carrier because of the problematic documents(Hamad, 2017).

\section{Risk Related to the Documents}

There are a number of risks to which the bank is exposed because of the documents submitted to it. It may be related to the inaccuracy, inadequacy, correctness, falsity or lack of general or special conditions of the bank.

As a result of complex process and interactions between the bank and traders in letter of credit transaction, there is a high chance for the occurrence of the documentary discrepancy. The risk of economic loss and dishonoring presentation by the bank will increase when there is no option to resolve discrepancies(Hamad, 2017). Such discrepancy can be considered as a significant risk for Jordanian exporters. 
According to ICC global survey, documentary discrepancy in letter of credit transaction is about 26$29 \%$. This is further compounded as more than $60 \%$ of respondents felt that the lack of harmonization of compliance standards create problems and challenges to the international business society.(International Chamber of Commerce)Documentary discrepancy rate in the USA is considered about $73 \%$ while in the UK it has been estimated up to 50-60\%(Mann, 2000) Unfortunately there are no statistics about the discrepancy rate in Jordan.

\section{Country Risk}

The customer good reputation, his ability to pay and his good financial situation sometimes are not enough for banks to eliminate the credit risk. The general policy and situation of the country in which the bank operates have an important effect in this regard. For example, political stability may change the client's ability to meet his obligations, as well as the situation of economic situation, economic fluctuations and legislative conditions of the country must be considered in the business transactions(Baker\& John, 2008).

\section{ANALYSIS \& DISCUSSION}

\section{C.1. MECHANISMS TO REDUCE THE RISK IN ISLAMIC OR CONVENTIONAL LETTER OF CREDIT}

The main objective of letters of credit is to ease the process of international trade. However, its special characteristics may increase the risks that the parties can face while utilizing this instrument as a payment method in international trade. For example, exclusive use of documents, geographical distance, absence of efficient prosecution, the diversity of legal system at the global level and restricted application of fraud rule can be considered reasons for different risks in letter of credit(Hamad, 2016). After the researcher showed previously the risks that Jordanian traders can face when using letter of credit, this section will explain the most important legal and practical solutions to these risks under the Jordanian practice.

\section{Comprehensive Regulation}

Solving letter of credit problems will lead to the flourishing of foreign trade, and so export operations increase, and the Jordanian imports decrease.(Thaher \& Abdul-Jalil, 2006).Starting from this point, Jordanian legislator should always give a huge care to letter of credit as it is considered as an important instrument in international trade to finance export and import in general. More evidence is provided to support the idea that not regulating the letter of credit risk is the reason for the uncertainty in global trade. Chart 2 illustrates the usage rate of letter of credit in import and export in worldwide trade.

From charts 2 it can be seen clearly that the usage rate of letter of credit- import and export- has declined from 44\% in 2011 to 38\% in 2016 in export letter of credit, and 39\% in import letter of credit. The international chamber of commerce confessed that operational problems, coupled with the relatively excessive cost and paperwork and the process intensive nature of $\mathrm{L} / \mathrm{C}$ transactions are propelling traders to seek out new payment alternatives. The increase in short-term export credit insurance and increases in 
the use of international factoring to finance export receivables also support the contention that traders are actively seeking out alternatives to the traditional commercial letter of credit (International Chamber of Commerce).

It is noteworthy that, Jordanian legislator has neglected letter of credit and did not regulate it neither by special legislation nor by inoculating some articles into commercial acts. While there are some Arabian countries that have regulated the rules about letters of credit by inserting some articles addressing the function of these instruments specifically into their commercial acts such as Egypt, Iraq, UAE, and Qatar (Alawamleh, 2013).

Even this approach that has been followed by the pervious listed countries cannot help to close the loophole in the Jordanian text law as these countries did not regulate any special text regarding the risks under letter of credit, Therefore, there is no need for basic articles to illustrate what the letter of credit definition and type and main principle are because UCP 600 already mentioned all of that in articles $(2,3,4,5,7,14,34)$ and this cannot help to reduce the risks of letter of credit.

What we really need is a comprehensive regulation which addresses the basics, the risks and the remedy, fraud exception and standard, a regulation that can combined the UCP 600 articles, Article 5109 of UCC and articles 15,19,20 of the UNCITRAL Convention. Even if UCP 600 is not comprehensive, Most, if not all, letter of credits in international transactions are governed by the International Chamber of Commerce (ICC) Uniform Custom and Practice for Documentary Credits, ICC Publication No. 600 (Buckley \& Xiang, 2002). UCP 600 are still the most advance rules that govern the operation of letter of credit.

The importance of Article 5-109 of UCC is that it is fully allocated to letters of credit the Article 5109 of UCC helps in finding a way for further harmonization of Jordanian law with international regulations, besides flexibility in practice, to meet technological changes and keep the competitive position of LC in international trade. Further, this article is important to adopt because it contains relevant provisions in $\mathrm{LC}$ fraud exception and covers circumstances necessary for granting injunction.

Besides that, articles 15,19,20 of the UNCITRAL Convention are successful in addressing major aspects of fraud rule developed by national courts, and they offer a precise and useful guideline. Article 19 (1) lists the types of misconduct by beneficiary, which result in the application of fraud rule both under letter of credit contract and underlying sales contract. Also, the Convention provides guidance for actions which victims of fraud can take by either withholding payment or refusing to honor presentation (bank) and applying for injunction remedy at court (applicant) in order to prevent issuing bank from honouring fraudulent presentation.

In the researcher's opinion, following the approach of the aforementioned countries (Egypt, Iraq, UAE, Qatar) is a step back for the present or in the future for Jordan, as we have not waited for more than a hundred years for superficially rules that does not help in anything, but if the legislator wants to regulate it, it must be regulated in a comprehensive way that covers all aspects. 


\section{Proposed Solutions for Applicant to Overcome the Risks Faced in Islamic or Conventional} $\mathrm{L} / \mathrm{C}$

It has been mentioned previously that importer (buyer-applicant) are the victims in most cases of credit risks in international trade. Therefore, it is worth studying the preventive methods that the Jordanian buyer can follow in a comprehensive manner.In addition, the Jordanian legislator should give more attention to the Jordanian buyers, who is the weakest party in the letter of credit transaction(Alavi, 2017), by establishingrules that would protect them further in the event of any defect in the letter of credit process.

Furthermore, Jordanian buyer should always keep in mind that preventive methods can be acceptable only if their application will prevent a higher expense than their own costs. For that, Jordanian applicant is strongly recommended to use a thorough and comparative cost-benefit analysis before choosing any preventive methods to use in international trade(Alavi, 2016).

The independence principle is the main aspect which creates a weaker position for Jordanian buyers against abusive demands of beneficiary.The principle of autonomy in letter of credit sometimes produces unwanted findings like the system protecting fraudsters. On such occasions, depending on strict compliance principle and the rejection of non-complying documents by bank will be the only defense of Jordanian buyers. However, this defense might not work when the beneficiary determines to obtain payment based on presenting fraudulent documents. On the other hand, the beneficiary has the upper hand against the issuing bank and account party in which, regardless to any dispute on the contract of sales, he is entitled for payment upon tender of complying documents. Such upper hand can be an incentive for abusive demand for payment or presentation of fraudulent documents by beneficiary( Alavi, 2017).

From the discussion above and according to the principle of autonomy, as long as documents correspond with the credit apparently, issuing bank should pay the seller his goods value without concerning any restriction of the sales contract. However, the bank's checking of the documents without examining the real goods, constitutes connatural disadvantage of principle of independence for letter of credit(Hao\& Xiao, 2013).

\subsection{Checking the Credibility of the Seller}

In the beginning, and before Jordanian buyers enter any sales contract with sellers, they need to gather information about the credibility of his business partner. Moreover, Jordanian buyers are recommended to contact the local banks in partner location to know about his credit history and his current financial situation as this can be a great help to the Jordanian buyer to understand with whom he is dealing with (Zhang, 2011). From an economic perspective, the cost of collecting information about the seller's financial situation is less than the future loss as a result of being defrauded by a fraudulent beneficiar(Alavi, 2016). 
Jordanian buyers are strongly recommended to conduct a deep investigation about the seller's financial situation before concluding any contract with him. This suggestion is also for the Jordanian exporters or banks when they are looking for trade partners.

\subsection{Use of Pre-Shipment Inspectors}

Similar to any other transaction in international trade, letter of credit contains different risks. Frequently, Jordanian buyers bear most of these risks as they need to pay the beneficiary depending on documents, not on goods(Alavi, 2016).

To protect themselves from various risks in international trade, Jordanian buyers can appoint an independent inspector to ensure the quality and quantity of the cargo(Zhang, 2012). Doing that will defiantly increase the cost of trade, but it can help to reduce the risk of fraud in letter of credit(Shohana, 2008).Jordanian buyers can also appoint someone or even themselves to go to the loading port to check the goods and supervise the loading operation(Meral, 2012).Further, it is much better if the Jordanian buyer or the person that Jordanian buyer appoints remain on the ship during transit to Jordan.

\subsection{Use of performance Bonds}

Combining performance bonds with letter of credit is the best preventive method for the Jordanian buyers to protect themselves from fraud risk in letter of credit. By receiving this guarantee, Jordanian buyers' business partner are forced to perform their contractual obligations(Zhang, 2011). If Jordanian buyers business partner does not perform his contractual obligations, this will oblige the issuing bank of the performance bond to pay Jordanian buyers solely upon a demand by themselves the amount stipulated in the performance bond (Shohana, 2008).

Jordanian buyers are strongly recommended to use letter of credit combined with performance bond,even if the use of performance bonds might make transactions more complex and increase the costs due to a service charge by the bank. However, this guarantee can reduce the risks of fraud to the lowest level in letter of credit transaction.

\subsection{The Use of Time Drafts Instead of Sight Drafts}

Using sight drafts means that the payment to the beneficiary will be immediately after the bank accept the documents submitted by the seller, while using time drafts means that the payment to the beneficiary will be on a specific date after the bank accept the documents submitted by the seller. Utilizing time draft can give the Jordanian buyers a huge opportunity to check the goods when they arrive and before the date of payment, while, using a sight draft will deprive the Jordanian buyers from such an opportunity as it makes the inspection of goods impossible and creates a chance of fraudulent conduct by the beneficiary(Alavi, 2016). Therefore, Jordanian Buyers are strongly recommended to use time drafts instead of sight drafts.

\subsection{Checking the Position and Capacity of the Contractual Vehicle}


Jordanian buyers are recommended to insert a condition in the underlying sale contract regarding the contracted ship name and the date of shipment(Alavi, 2016).This condition gives Jordanian buyers the opportunity to use the Lloyd's List Intelligence database in order to confirm the location of the contracted ship, the availability of the contracted ship, its capacity, and the approximate date of arrival to its destination(Zhang, 2012). In addition, Jordanian buyers have to be more aware about the diverse terms of shipment and allocation of risks and obligation to each partner accordingly. The wide knowledge about shipping terms can be a huge advantage to the Jordanian buyers in international trade. For example, while concluding a sale contract, Jordanian buyers are advised to use FOB shipping terms instead of CIF shipping terms(Hao \& Xiao, 2013).

\subsection{Confirming the Authenticity of a Bill of Lading}

Jordanian buyers are recommended to ask the beneficiary to send them a copy of the bill of lading and other documents of title by any means of communication before their presentation to the bank. Access to such documents will give the Jordanian buyers the opportunity to determine the authenticity of these documents as well as their issuing body. Jordanian buyers are advise to conduct a deep search about the transporter address and phone numbers beside saving the conversation with the issuer while confirming the documents authenticity(Alavi, 2016).

\subsection{Use of 'Sales on Approval' Clause}

The sale on approval is a term that has been used in international trade and represents the right of the buyer to approve the contracted goods before the seller receives the payment. According to the sale on approval clause, firstly, the buyer has to approve the conformity of the delivered goods with the terms and condition of the underlying sale contract before the seller can obtain the payment from the issuing or conforming bank. Further, sale on approval clause can be used to stop payment against non-existing goods to dishonest seller(Alavi, 2016).

If sale on approval term is used in letter of credit, the situation where no goods exist at all or the situation of inferior quality or quantity of delivered goods, will be discovered during the examination of goods for approval(Zhang, 2012). Then Jordanian buyers may have a straightforward evidence to prevent the bank from honoring the payment.

3. Proposed Solutions for Jordanian Beneficiary to Overcome the Risks Faced in Islamic or Conventional L/C

The most important preventive measures which can help the Jordanianseller to mitigate the risk of letter of credit are the following:

\subsection{Prudence in Drafting Sales Contracts by Jordanian Exporters}

The Underlying sale contract is considered as a row base for letter of credit process. Therefore, Jordanianexporters are recommended to pay enough attention when they are drafting it. Furthermore, Jordanianexporters should be fully aware of the required documents. In addition, Jordanianexporters should be aware of the different scenarios in international trade and they should 
always have a backup plan in case of any problems arise in underlying sale contract. Jordanianexporters are recommended to use this technique in order to reduce the risk in letter of credit(Alavi, 2016).

\subsection{Checking the Letter of Credit after Jordanian Seller Receives It}

Jordanian exporters need to check the letter of credit that they receive from the issuing bank carefully and immediately and that to have a sufficient time for any amendment and to avoid the failure of not obtaining the required documents (Zhang, 2012).

There are many aspects requiring attention when the letter of credit is checked by the Jordanian exporters: They should check the validity of the letter of credit itself, the financial situation of the issuing bank, the terms and condition for honouring the payment, the appropriateness of the period of validity (Alavi, 2016)required documents to avoid soft clause; and whether the letter of credit terms and condition are in compliance with the clauses of the underlying contract(Hao\& Xiao,2013).

\subsection{Cooperation with Internal Units and Banks}

Jordanian exporters should always keen on effective cooperation with the units inside banks. Letter of credit is a risky transaction, thus once a letter of credit transaction is involved, all the units inside the bank should cooperate with each other to reduce the possibility of risks to the lowest level by gathering as much information as possible about transaction. Furthermore, Jordanian exporters must also cooperate with the advising bank in Jordan by asking it for advice if they found some ambiguous terms in letters of credit (Zhang, 2011).

\section{Solutions for Jordanian Islamic and Conventional Banks to Overcome the Risks of Letter of Credit}

In this part of the study, the possible preventive and proactive measures that Jordanian banks can take will be discussed and reviewed.

\subsection{Letter of Credit Guarantees}

Letter of credit is a contract based on personal consideration, in the sense that it is based on trust. But the amount of such trust varies from one operation to another depending on its circumstances(Hamo \& Mohammed, 2016). On this basis, banks often asks the person requesting the credit to provide a guarantee to approve his request to open the credit for the benefit of a beneficiary, so that, banks can execute on it if the customer fails to pay or delays payment (Hamo \& Mohammed, 2016).

Banks requests such collateral from the customer to avoid unforeseen circumstances or unforeseen risks, but not because of lack of trust. Therefore, these guarantees come in the second place in the bank's consideration after a good query on the client's financial and moral reputation (Hamo \& Mohammed, 2016).Banks in the letter of credit have a special guarantee that distinguishes it from the rest of the credit banking operations, which is the right to refrain from delivering the 
representative documents of the goods to the client (Hamo \& Mohammed, 2016). For this reason, the bank often resorts to obtain other collateral from the client as a cover for the credit it opens, in order to mitigate these risks or to prevent them from occurring (Hamo \& Mohammed, 2016).

\subsection{TheOffering of Super Service}

The bank super service was introduced as a proposal for the first time by UNCTAD in the1980s (Alavi, 2016). Bank super service means to impose some obligation on the paying bank to undertake an investigation about the validity, genuineness, or accuracy of the documents before making payment to the seller under letter of credit (Zhang, 2012).

Bank super service has received many criticisms, as it is not practical for banks to check the authenticity of many documents or signatures on these documents. The reason behind this impractical issue is the enormous number of shipping companies and agents in the world and the vast number of documents submitted to banks in letter of credit transactions.Furthermore, it is not the bank's job to look behind documents and verify their authenticity. Finally, the costs of providing this service is excessive, in addition, it is hard for the banks to access to an adequate communication networks in order to collect sufficient information about the authenticity of documents and signatures from different parties worldwide (Alavi, 2016).

As a reason for all previous criticisms, super service can be optional with an additional fee charge by banks, this means that clients can choose whether to use the super service or not. (Zhang, 2011) According to the interviews with the Jordanian banks such service is not available in Jordan.

\subsection{Further Investigation Where Fraud is Suspect}

Alongside banks super service, Jordanian banks must be more cautious when a doubt about fraud appears on the surface. When there is a doubt about fraud during documents examination process, banks have to alter their practice and takes more precautionary measures(Zhang, 2012). In addition, Jordanian banks have to check the submitted documents cautiously by making additional enquires and undertake a deep investigation about the documents to prevent fraud appearing(Zhang, 2011).

Jordanian Bank may not bear any responsibility based on UCP 600. However, if the bank applicant suffers loss from a successful fraudulent letter of credit transaction, the applicant potential bankruptcy may endanger the bank's interest for receiving reimbursement from him (Zhang, 2012).

\subsection{More Awareness in Conducting Daily Business}

Jordanian Banks are recommended to be more conscious in conducting their daily business. They are also advised to offer training to their staffs about fraud detective method in letter of credit and that to increase their awareness and knowledge about fraud scenarios under letter of credit (Alavi, 2016).In addition, Jordanian Banks should always check the documents presented by new or less-known clients (Alavi, 2016).

\section{CONCLUSION}


This study has found that risks related to the goods, fraud risk, issuing bank's negligence risk, risk related to the documents and country risk are among the famous risks that face Jordanian traders and banks.The risks of the documents and goods are of the main risks that Jordanian banks face in letter of credit transaction especially Islamic Banks which care about the goodsas well as the documents. The researcher concludes to a point that even if the bank deals with documents and not with the goods, the risks of non-compliance of the documents with the goods will definitely affect the bank. That is because the bank will lose a very important guarantee which is the goods. Further, the customer may face insolvency because of that, and the bank might not get any reimbursement. Also, this study found that all Jordanian Banks are exposed to the risk of unsettled political conditions that prevent banks from implementing the credit due to wars or economic siege as Jordan is located in hot zone surrounding by many countries that have political issue and non-stable conditions. This study also found that legislative risk is one of the biggest challenges that hinder the development of the banking sector as a whole in Jordan. The government does not study the consequences of its instructions and laws. The Jordanian government should remember that the banking sector is the largest and most important sector in Jordan, and they should develop this sector and not eliminate it through instructions restricting and slowing banking business.

To transfer the application of letter of credit from risky transaction to a safe and trusted instrument in international trade, Jordanian traders are strongly recommended to conduct an extensive investigation on the credibility of business partners before entering into any contract with them. Moreover, Jordanian traders are strongly advised to employ an independent inspector. Another advice is to insert provisions regarding the name of the contracted vehicle and date of shipment in the underlying contract. Jordanian traders are recommended to use FOB terms instead of CIF which are most frequently used. Also Jordanian traders are recommended to conduct a search on authenticity of the carrier's address and phone numbers besides legally recording the conversation with the issuer while confirming the authenticity of the bill of lading, and to insert a provision in the contract of sales to obligate the seller to send the bill of lading to the banks and link that to payment. In addition, because there are no insurance companies in Jordan that offer suitable insurance policies against fraud risk in letter of credit transaction, the researcher suggests that fraud risk in a letter of credit transaction can be categorized under a failure to perform the contract if the payment for nonexistent goods is the seller's failure to fulfill the contract of sales.

Regarding to the international chamber of commerce practice towards the silent position about the risk of fraud, whether it is positive or negative, the researcher's point of view is that the absence of legal texts is negative. The researcher strongly recommends the Jordanian legislator to issue, in the light of the Jordanian banks practice, a law or special provisions that can be added to the commercial act, due to the lack of any legal provisions on letter of credit in Jordanian legislation. The researcher believes that there is no objection to gain international norms as a national law derived from customs and added the fraud 
rule as the American has done. Furthermore, it is suggested that the ICC should take into consideration that their approach has, at least from a Jordanian perspective, proved to be ineffective and, accordingly, introduce some provisions to regulate the fraud problem in their next publications and revisions.

\section{REFERENCES}

Al-Amaren, E. M., Ismail, C. T. B. M., \&Nor, M. Z. B. M. (2019). The Interplaybetween Performance Bonds and The Principle of Independence of The Bank's Commitment in Jordan. Yustisia Jurnal Hukum, 8(2), $152-163$.

Al-Amaren, E. M., Ismail, C. T. B. M., \& Nor, M. Z. B. M.. (2020). The Blockchain Revolution: A GameChanging in Letter of Credit (L/C)?. International Journal of Advanced Science and Technology, 29(3), 6052 - 6058. Retrieved from http://sersc.org/journals/index.php/IJAST/article/view/6747

Al Amaren, E. M., \& Indriyani, R. (2019).Appraising the Law of Wills in A Contract. Hang Tuah Law Journal, 3(1), 46-58.

Al-Amaren, E. M. (2018). The Internationalization of The International Contract According to International Theories and Conventions. Yustisia Jurnal Hukum, 7(3), 428-442.

Alavi, H. (2017). Fraud in Documentary Letters of Credit; A Comparative Study of Excising International Legal Frameworks. Bratislava Law Review, 1(1), 48-69.

Alavi, H. (2016). Mitigating the risk of fraud in documentary letters of credit. Baltic Journal of European Studies, 6(1), 139-156.

Alavi, H. (2015). Autonomy Principle and Fraud Exception in Documentary Letters of Credit, a Comparative Study between United States and England. International and Comparative Law Review, 15(2), 47-68.

Alavi, H. (2017). Risk Analysis in Documentary Letter of Credit Operation. Financial Law Review, 1 (aheadof-print).

Alawamleh, K. J. A. (2013). Documentary Credits and Independent Guarantees: A Critique of the 'Fraud Exception 'Position in English and Jordanian Law (Doctoral dissertation, University of Central Lancashire).

Alrabei, A. M. A. (2017). Perception of Jordanian Banks Employees on the Relationship between Accounting Information Quality (AIQ) and Documentary Credits. International Journal of Applied Business and Economic Research, 15(19).

Bouguerra, I\&Bellaouar, S. (2015). Difficulties Facing Jordanian Banks Related to Issued Letters of Credit’. El-Bahith Review 15: 55.

Buckley, R. P., \&Gao, X. (2002). Development of the fraud rule in letter of credit law: The journey so far and the road ahead. U. Pa. J. Int'l Econ. L., 23, 663.

Che Hashim, R., \& Mahdzan, N. S. (2014). Fraud in letter of credit transactions: The experience of Malaysian bankers. International Journal of Law, Crime and Justice, 42(3), 224-236. 
Dolan, J., \& Baker, W. B. (2008). Users Handbook for Documentary Credits under UPC 600. International Chamber of Commerce, Forthcoming, 08-37.

Hamad, A. M. (2019). End of The Minister's Legal Status In Palestinian Law. Hang Tuah Law Journal, 3(1), 59-68.

Hamo, N \& Mohammed, B. (2016).The Risk of Letter of Credit and the Way to Reduce it. Al-Rafidain Journal of Rights 13, no.48

Han, C. R., Nelen, H., \& Joo, M. Y. (2015). Documentary credit fraud against banks: analysis of Korean cases. Journal of Money Laundering Control.

Islam, S., \& Ahamed, S. (2008). Preventing Letter of Credit Fraud. Journal of Business and Economics Vol 3 , No. 2

Mann, R. J. (2000). The role of letters of credit in payment transactions. Michigan Law Review, 2494-2536.

Meral, N. (2012). The Fraud Exception in Documentary Credits: A Global Analysis. Ankara B. Rev., 5, 39.

Mentschikoff, S. (1955). Letters of Credit: The Need for Uniform Legislation. U. Chi. L. Rev., 23, 571.

Monteiro, F. (2007). Documentary Credits: The Autonomy Principle and the Fraud Exception: A Comparative Analysis of Common Law Approaches and Suggestions for New Zealand. Auckland UL Rev., 13, 144.

Obeidat, M \& Al-Khashraom, A. (2009).The Risks of Letter of Credit, Al-Manara Magazine15, no. 2 (2009):159.

Ramadan,I. (2015). Towards the Bank's Commitment to Examine Documentation in Documentary Credit in light of the Bahraini and Egyptian Trade Law and Circular 600 of 2007 issued by the Paris Chamber, Egyptian Journal of Legal and Economic Studies (4th Issue) March (2015): 98-42, 46.

Thaher, A. H., \& Abdul-Jalil, T. H. (2006).Problems of Export Letters (LCs) from the Point of View of Jordanian Exporters. Dirasat Journal, 33(1), 79.

The International Chamber of Commerce Global Survey 'Rethinking Trade and Finance’. 2014.

Yan, H., \& Xiao, L. (2013). Risk Analysis of Letter of Credit -Based on Principles of' Independence 'and' Strict Compliance'. International Journal of Business and Social Science, 4(9).

Zhang, Y. (2012). Documentary letter of credit fraud risk management. Journal of Financial Crime.

Zhang, Y. (2011). Approaches to Resolving the International Documentary Letters of Credit Fraud Issue (p. 173). University of Eastern Finland. 